\title{
Work Life Balance: An Analysis
}

\author{
Renji Issac and Dr. Krishnaveni Ramesh
}

\begin{abstract}
Both professional and personal life is important to every human. Any type of distraction can cause disequilibrium in their life and may result into job loss or penalty and strain both in work and in family life. The productivity, health and relationship may suffer.

The earning capacity matters and nothing else matters. most of the corporate executives are committed to work only and often clashes with multiples family roles. Even if they are single, has the commitment and roles with parents, siblings and friends. Equilibrium between job and life can benefit in many ways and it is necessary.
\end{abstract}

Keywords--- Work Life Balance, Roles, Commitments, Quality.

\section{INTRODUCTION}

$\mathrm{T}$ ODAY'S business world is complex and the role of employees in organizations demand cent percent commitment and achievement. The employees facing challenges with their life and official roles because of fast pace of life and high demanding duties. The article tries to find out the different elements that affect quality of one's total life lies between personal and professional ends.

Every employee committed towards their work, responsibilities.Their accountability make them to forget their families. Most of them are ready to die for their livelihood. Often they are in dilemma or in conflict between their domestic people and professional needs. They suffer both inter personal and intra personal imbalance in meeting different aspects and multiple roles of life. The increased requirement of concentrating for professional and business goals and roles in personal life makes imbalance in work and life. Work life balance is a delicate issue and need to handle with utmost care and caution with application of creativity, to balance personal and job roles.

Work life balance is a process of arranging the career goals and personal commitments in a holistic manner, neither the work nor the personal things disturb one another (kvande, E2009).

\section{LiteratURE REVIEW}

Rajadhyaksha and Velgach (2009) also found that women experienced significantly higher family interference with work as compared to men. However there were no significant differences between men and women in the experience of work interference with family.

Renji Issac, Research Scholar, Management, Karpagam University, Coimbatore.

Dr. Krishnaveni Ramesh, Associate Professor, Department of Management, Karpagam University.

DOI: $10.9756 /$ IJRAS.8156
Quality of work life is becoming an imperative issue to achieve the goals of the organization in every sector whether it is education, service sector, banking sector, tourism, manufacturing, etc. Attrition, employees commitment, productivity etc. depend upon the dimensions of Quality of work life i.e. job satisfaction, organizational commitment, reward and recognition, participative management, work life balance, proper grievances handling, welfare facilities, work environment, etc.

The concept of work-life balance in human resources includes employee's proper prioritizing between their work (career and ambition) and their lifestyle (health, pleasure, leisure, and family). In recent years, the literature review on the concept has been framed up in view of its gained popularity within academic and corporate circles with the main objective being to have prosperity within societies in general and the well being of companies' employees.

\section{ELEMENTS OF WORK LIFE BALANCE}

Work life balance is influenced by many factors. From the important are as follows:

- Organizational communication and relations

- Problem solving communication and equations

- Work environments and its merits.

- Priority for employees voice

- Caring of employee requests, complaints and suggestions.

- Family care and support.

- Communication and understanding within the family

Causes of Work Life Imbalance

- Multi tasking and overload

- Fast work requirements

- Unnecessary burdens of promises

- No friend, family relationships

- No prioritization in work schedule

- Inefficiency in managing job.

- No separation between work and life.

- Unrealistic approach to life and work.

Symptoms

- Short temper nature

- No joy and continuous stress

- Continuous worry

- Fell as sick

- Un controlled emotions and expression of mood variation

- Addictions

- Depressions

- Less productivity 


\section{Consequences}

- $\quad$ Fatigue

- Distress

- Poor health

- $\quad$ No time for domestic duties

- Increased expectations

\section{Remedies}

- Good health

- Take enough rest

- Enjoying vacations and travel

- Volunteer works

- Set time limits for work and life

- Flexible work times with earnings

- Legislations and agreements

- $\quad$ Socializing and group therapy.

\section{MODELS OF WORK LIFE BALANCE}

\section{Traditional Work-Life Balance Model}

- Clear boundaries are defined between work and life.

- They view work as a separate entity from personal life.

- This is your typical 9-5 work model.

- $\quad$ People in this model, don't do any work related things once they are out of office.

- They don't like to talk about the details of their work to anybody outside.

- They lack passion in the work they do.

- They treat work as a means to earn money and nothing more.

\section{Imbalanced Work-Life Balance Model}

- They don't view work as a separate entity.

- The boundaries of work extends into their personal life.

- They work really long hours.

- They always bring work to home. "I'm working tonight (or this weekend)" is a typical excuses for them to avoid all personal events.

- When they are forced to go out and participate in any social activities, most of the time, they are on their phone checking emails, or on phone talking with someone at work.

- They love the technology aspect of their work (or the business aspect). They are very much obsessed with it, and typically end-up spending lot more time that necessary to complete a project.

\section{Purposeful Work-Life Balance Model}

- $\quad$ People in model understand that life is a single entity, and anything we experience (work and personal) is all part of this single life entity.

- They have identified and defined a clear purpose and meaning to their life. Their purpose in life is typically aligned with the kind of work they do professionally that brings both money and happiness.
- Family, friends, work, and nature are all part of their life that they enjoy and love.

- They are extremely passionate about their work. If they don't love what they do, they'll not stop until they find a job that they love to do.

- They'll bring work to home if necessary, and at the same time, they'll also take a break from work if necessary.

- Their family and friends are supportive of their work, and they'll encourage to make a difference.

- They always seem to find a way to spend quality time with their family, friends, and community.

- They always take a positive attitude towards everything in life.

- They don't go to work just because it pays money, and gives them the opportunity to work on the technology (or the business) that they love. They go to work, because the work they do is aligned with the clear purpose they have defined for themselves in their life.

\section{BENEFITS OF WORK LIFE BALANCE}

- Attract and retain talent

- more creative

- more healthier

- No burnout

- Brighter future

- Less stress, absenteeism and health cost

- Improved staff morale and engagements

- Improved customer satisfaction

- Improved recruitment, retention.

\section{CONCLUSION}

Work life balance is reality while approaching people with prioritization of things and practicing certain principles and efforts taking for it.

\section{REFERENCES}

[1] R. Yadav and A. Khanna, "Literature Review on Quality of Work Life and Their Dimensions", IOSR Journal of Humanities And Social Science (IOSR-JHSS), Vol. 19, Pp. 71-80, 2014.

[2] Ndedi, Alain, Shafak and Tanju Fidel, "Analysing the Literature Review on Work-Life Balance", 2015. Available at SSRN: https://ssrn.com/abstract $=2545287$

[3] Ramesh Natarajan, “3WLB models”, The geek stuff.com, 2012.

[4] www.americanexpress.com/open/5 benefits of Worklife balance

[5] www.greaterworksolutions.com worklife balance.html

[6] www.psychologytoday.com/worklife balance/partI

[7] www.mindtools.com/pages/article/the wheel of life:find balancein your life

[8] www.wisdom.srisriravisankar.com/5skills you must develop in need in life and business. 